\title{
A Queensland Treaty: Current Steps and Potential Challenges
}

Last July, Queensland's Deputy Premier and Minister for Aboriginal and Torres Strait Islander Partnerships, Jackie Trad, announced that the State would begin a conversation about treaty with Aboriginal and Torres Strait Islander peoples. ${ }^{1}$ In doing so, Queensland joined Victoria, and the Northern Territory in committing to and initiating formal agreement-making processes with Indigenous Australians. ${ }^{2}$ These are significant developments: as the Uluru Statement from the Heart records, treaty making is a key aspiration of Aboriginal and Torres Strait Islander peoples. ${ }^{3}$ In this short article, I will explain what a treaty is, consider the question of sovereignty, outline the steps undertaken thus far in Queensland, situate this development in its larger national context, and explore several challenges moving forward.

\section{What are treaties?}

Treaties are accepted globally as a means of reaching a settlement between Indigenous peoples and those who have colonised their lands. They have been struck in the United States and Aotearoa New Zealand, and are still being negotiated in Canada today. In contrast, no treaty was signed between Aboriginal and Torres Strait Islander peoples and the British Crown at first contact or in the early years of Australia's European settlement.

It is not clear why this was the case but a number of theories have been proposed. These have included suggestions that because the British arrived with a substantial military force they did not need to negotiate or develop productive relationships with the Indigenous political communities they encountered. ${ }^{4}$ Others have suggested that the distinctive foundations of colonialism meant there was little opportunity to develop relationships based on trade. ${ }^{5}$ Still others argue that the racist attitudes of the day may also have been influential. In 1837 a Select Committee on Aborigines reported to the United Kingdom House of Commons, declaring that Aboriginal people were 'barbarous' and 'so entirely destitute...of the rudest forms of civil polity, that their claims, whether as sovereigns or proprietors of the soil, have been utterly disregarded ${ }^{6}{ }^{6}$ Or, perhaps as Palawa lawyer Michael Mansell argues, the primary reason why no treaty was negotiated is not because Aboriginal people were seen as inferior but because 'the character and disposition of the original white settlers in Australia was so rudimentary'.

It is likely that a combination of these factors contributed to the decision by the British not to enter into negotiations. That decision has affected the Australian state's relationship with Aboriginal and Torres Strait Islander peoples. It was not until 1992, that the High Court of Australia recognised that Aboriginal and Torres Strait Islander peoples' rights to land under their traditional law and custom had survived British acquisition of sovereignty. ${ }^{8}$ However, the Court has not accepted that Indigenous sovereignty

\footnotetext{
${ }^{1}$ Annastacia Palaszczuk, Jackie Trad and Leeanne Enoch, 'Historic Signing of “Tracks to Treaty” Commitment' (Media Release, 14 July 2019).

2 See generally Harry Hobbs and George Williams, 'Treaty-Making in the Australian Federation' (2019) 43(1) Melbourne University Law Review 178.

3 Referendum Council, 'Uluru Statement from the Heart' (Statement, First Nations National Constitution Convention, 26 May 2017).

${ }^{4}$ Peter Russell, Recognising Aboriginal Title: The Mabo Case and Indigenous Resistance to English-Settler Colonialism (University of Toronto Press, 2006) 70-71; Bain Attwood, Possession: Batman's Treaty and the Matter of History (Miegunyah Press, 2009) 94.

${ }^{5}$ Stuart Banner, Possessing the Pacific: Land, Settlers and Indigenous People from Australia to Alaska (Harvard University Press, 2007) 18-19.

${ }^{6}$ Report of the Parliamentary Select Committee on Aboriginal Tribes (1837), 125-6.

${ }^{7}$ Michael Mansell, Treaty and Statehood: Aboriginal Self-Determination (Federation Press, 2016) 105.

${ }^{8}$ Mabo v Queensland (No 2) (1992) 175 CLR 1.
} 
persists, ${ }^{9}$ and Australian law has never expressly recognised that Aboriginal and Torres Strait Islander peoples have an inherent right to self-government. ${ }^{10}$

A treaty or treaties could change this. This is because a treaty is a special kind of agreement that satisfies three conditions. ${ }^{11}$ These conditions are drawn from contemporary international human rights instruments concerning Indigenous peoples and from modern comprehensive land settlements being negotiated in Canada. First, a treaty must recognise Indigenous peoples as a distinct political community based on their status as prior self-governing communities who owned and occupied the land now claimed by the state. Second, a treaty is a political agreement that must be reached by way of a fair process of negotiation between equals. Third, a treaty requires both sides to accept a series of responsibilities so that the agreement can bind the parties in a relationship of mutual obligation. As part of this, Indigenous peoples are expected to withdraw all current and future claims relating to historical and contemporary dispossession. Significantly, however, the state must also accept certain conditions, including the fact that Indigenous nations retain an inherent right to sovereignty. As an exercise of that right, a treaty recognises or establishes structures of culturally appropriate forms of decision-making, amounting to a degree of self-government in internal and local affairs.

Every settlement reflects the specific aspirations of the participants, but all treaties contain similar elements. In Canada, for example, modern treaties include agreements relating to land, rights over resources, and cultural heritage. Importantly, they also recognise culturally appropriate forms of decision-making, amounting to a degree of self-government in internal and local affairs, and provide recurrent financing as a means to ensure their autonomous functioning. ${ }^{12}$ Drawing on the modern treaties in Canada, a Queensland treaty or treaties could empower Aboriginal and Torres Strait Islander nations with the capacity to wield greater control over land and resources. It could also empower Queensland First Nations with the legal authority to make decisions over the administration of justice, family and social services, healthcare, and language and cultural education.

\section{The question of sovereignty}

Aboriginal and Torres Strait Islander peoples maintain that sovereignty was never ceded, ${ }^{13}$ and conceive a treaty process as being 'about recognition of the ongoing dimensions of that sovereignty'. ${ }^{14}$ A treaty will recognise Indigenous sovereignty, but it will also be subject to Australian law. This means that federal and state law will apply where an inconsistency or conflict arises with a treaty or Indigenous law-making. Many First Nations peoples reject this. Tanganekald, Meintangk and Boandik professor of Law Irene Watson, for instance, argues that internal forms of sovereignty or recognition of an Indigenous right to self-determination within Australian law will 'inevitably reinstate colonial law', ${ }^{15}$ and leave Indigenous peoples 'subservient to the rules of the state'. ${ }^{16}$

Other First Nations people disagree, and do not see any conflict. For instance, Senator Patrick Dodson, a Yawuru man, argues that a treaty could

\footnotetext{
${ }^{9}$ Coe v Commonwealth (No 2) (1993) 68 ALJR 110, 115.

${ }^{10}$ Harry Hobbs and George Williams, 'The Noongar Settlement: Australia's First Treaty' (2018) 39(1) Sydney Law Review 1, 27.

${ }^{11}$ Ibid, 7-14.

${ }^{12}$ Christina Godlewska and Jeremy Webber, 'The Calder decision, Aboriginal title, and the Nisga'a' in Hamar Foster, Heather Raven and Jeremy Webber (eds), Let Right be Done: Aboriginal Title, the Calder Case, and the Future of Indigenous Rights (University of British Columbia Press, 2007) 1, 17-18.

${ }^{13}$ Uluru Statement (n 3); 'Aboriginal Sovereignty: Never Ceded' (1988) 23(91) Australian Historical Studies 1.

${ }^{14}$ William Jones, 'Recognising Aboriginal Sovereignty: Implications for the Treaty Process' (Speech, ATSIC National Treaty Conference, 27 August 2002).

${ }^{15}$ Irene Watson, Aboriginal Peoples, Colonialism and International Law: Raw Law (Routledge, 2015) 2.

${ }^{16}$ Ibid 91. See further: Irene Watson, 'First Nations, Indigenous Peoples: Our Laws Have Always Been Here' in Irene Watson (ed), Indigenous Peoples as Subjects of International Law (Routledge, 2018) 96.
} 
acknowledge the dispossession that occurred and establish a settlement process to redress and resolve historical grievances. It could also provide a framework to recognise our unique rights and cultures as Indigenous people and set out mutually agreed terms for our relationship with the Australian government. ${ }^{17}$

Along the same lines, Eualeyai and Kamillaroi scholar Larissa Behrendt has pointed out that for many First Nations peoples, sovereignty does not mean secession. Instead it

is a device by which other rights can be achieved. Rather than being the aim of political advocacy, it is a starting point for recognition of rights and inclusion in democratic processes. It is seen as a footing, a recognition, from which to demand those rights and transference of power from the Australian state, not a footing from which to separate from it. ${ }^{18}$

All this is to say that sovereignty is a complex term. There is a wide diversity of views among Aboriginal and Torres Strait Islander peoples over its meaning. Each First Nations community will need to decide amongst themselves whether a treaty process subject to Australian law is nonetheless worth exploring.

\section{What is happening in Queensland?}

As this short discussion suggests, we may be getting ahead of ourselves. It is too early to tell whether the Queensland process will result in meaningful settlements that meet Aboriginal and Torres Strait Islander peoples' aspirations for a restructured relationship with the state. The process is in its very early stages and negotiations will not begin for several years. This is sensible, because it is important that both the government and Aboriginal and Torres Strait Islander peoples are fully prepared before formal talks begin.

For First Nations, this means having a clear sense of what a treaty might mean for their communities, as well as a broad consensus on a negotiating position. Preparing for treaty negotiations can also enable Indigenous communities to engage in nation-(re)building, a valuable process regardless of the content, or even the completion, of a treaty. ${ }^{19}$ For the government, it is equally important that non-Indigenous Queenslanders understand what a treaty is and what its potential impact will be.

The Queensland announcement may have caught many people off-guard, but the State government has been consistent, if not especially vocal, in its support for treaty over the last few years. The government initially adopted treaty as part of their policy platform in 2016, just a few months after both Victoria and South Australia had formally committed to exploring treaty processes. That commitment was aspirational, but inchoate. It consisted of a single line pledging to commence negotiations 'within the next term of Parliament'. ${ }^{20}$

In the lead up to the 2017 State election the commitment was revisited. In three paragraphs, the government declared that it would 'establish \& authorise a Treaty Working Group within the next term of Parliament to begin negotiations'. ${ }^{21}$ It also provided detail on the role and composition of the Working Group. It would provide advice on the process and timing for negotiations, guidance on

\footnotetext{
${ }^{17}$ Patrick Dodson, 'Navigating a Path Towards Meaningful Change and Recognition' in Megan Davis and Marcia Langton (eds), It's Our Country: Indigenous Arguments for Meaningful Constitutional Recognition and Reform (Melbourne University Press, 2016) 180, 181.

${ }^{18}$ Larissa Behrendt, Achieving Social Justice. Indigenous Rights and Australia's Future (Federation Press, 2003) 99.

${ }^{19}$ Harry Hobbs, Alison Whittaker and Lindon Coombes, 'As the federal government debates an Indigenous Voice, state and territories are pressing ahead', The Conversation, 16 July 2019.

${ }^{20}$ Queensland Labor, Queensland State Policy Platform 2016 (State Conference of the Queensland Branch of the Australian Labor Party, 29 \& 30 October 2016) 93 [8.190].

${ }^{21}$ Queensland Labor, Putting Queenslanders First: State Platform 2017 (State Conference of the Queensland Branch of the Australian Labor Party, 28-29 July 2017) 118 [8.243].
} 
community engagement, and examine proposals for a permanent state-wide Aboriginal representative body. ${ }^{22}$ It would comprise of at least 50 per cent women, and include nominees from Traditional Owner Corporations, the Queensland Indigenous Youth Parliament and Aboriginal Controlled Community Organisations. The relevant Minister would also be able to appoint persons in their individual capacity based on their experience and expertise, but such appointments would comprise fewer than half the body. ${ }^{23}$ Following its establishment, regional forums would be held across the state to discuss its work and outline next steps. ${ }^{24}$

Treaty was not a headline issue in the 2017 state election campaign. Perhaps reflecting this fact, although the Labor government was returned, no announcement regarding the treaty process was forthcoming. ${ }^{25}$ Nonetheless, treaty remained party policy, and in 2018, reports indicated that the Queensland Indigenous Labor Network had authored a discussion paper exploring how the state could enter into negotiations with 'individual sovereign nations' ${ }^{26}$ It was not until July 2019 , however, that a firm commitment was issued.

On 14 July 2019, Queensland Deputy Premier Jackie Trad announced that the state would begin a conversation about a pathway to treaty with Aboriginal and Torres Strait Islander peoples. ${ }^{27}$ Trad explained her government's reasoning, stating that 'We hope that this process goes some way to right the wrongs of the past and sets the foundation for a new and just relationship towards our shared future'. Indigenous leaders reacted positively to the announcement, declaring 'We've been waiting for a long time for this'. ${ }^{28}$

To progress this commitment, the government established a bipartisan eminent panel of Indigenous and non-Indigenous leaders, co-chaired by Indigenous academic Jackie Huggins and former AttorneyGeneral Michael Lavarch. The other members of the panel are Indigenous academic Josephine Bourne, former Aboriginal and Torres Strait Islander Social Justice Commissioner, Mick Gooda, journalist Kerry O'Brien and former Governor-General, Dame Quentin Bryce. The panel will provide leadership and has begun to engage with key stakeholders across the state. The Treaty Working Group, discussed in the 2017 policy platform, has not yet been established. Once it is set up, it will lead consultations with First Nations, allowing them to discuss and reach agreement on what a treaty might contain. ${ }^{29}$ As noted, negotiations are unlikely to begin for several years.

\section{National context}

Treaty talk is increasingly common across the country. In February 2016, the Victorian Government announced its commitment to negotiate a treaty with Aboriginal Victorians. Following two years of consultations across the state the Parliament enacted Australia's first treaty bill in June 2018. The Advancing the Treaty Process with Aboriginal Victorians Act 2018 creates a basis for negotiating a treaty with Aboriginal people in the State. As the Act states, the Parliament sees a treaty as valuable in order to

\footnotetext{
22 Ibid.

${ }^{23}$ Ibid, 119 [8.244].

${ }^{24}$ Ibid, 119 [8.245].

${ }^{25}$ Alice Petrie and Michael Graham, 'Treaty Discussions in Australia: An Overview' (Research Paper No 4, Parliamentary Library and Information Service, Parliament of Victoria, May 2018) 10.

${ }^{26}$ Stephen Fitzpatrick and Michael McKenna, 'Queensland Considers Treaty Talks as Federal Bids Stall', The Australian, 17 July 2018).

27 Palaszczuk, Trad and Enoch (n 1); Queensland Government, Department of Aboriginal and Torres Strait Islander Partnerships, Statement of Commitment (2019).

28 Talissa Siganto, 'Queensland Government announces "conversation" to formalise Indigenous treaty', $A B C$ News, 14 July 2019.

${ }^{29}$ Queensland Government, Department of Aboriginal and Torres Strait Islander Partnerships, 'Path to Treaty'.
} 
Help heal the wounds of the past, provide recognition for historic wrongs, address ongoing injustices, support reconciliation and promote the fundamental human rights of Aboriginal peoples, including the right to self-determination. ${ }^{30}$

That same month, the Northern Territory government and representatives of the four Aboriginal Land Councils signed a memorandum of understanding, outlining how a treaty between the government and the Northern Territory's Aboriginal people should progress. The Barunga Agreement envisages a treaty as a substantive concept that will empower Aboriginal communities with real decision-making authority. At the same time, it understands treaty as offering the potential to ground "lasting reconciliation between the First Nations of the Territory and other citizens with the object of achieving a united Northern Territory'. ${ }^{31}$

Not all steps are moving ahead smoothly. In December 2016, discussion began between the South Australian Government and Indigenous peoples aimed at finalising a treaty. The following year, the state commenced negotiations with three Aboriginal nations: the Ngarrindjeri, Narungga and Adnyamathanha. However, the same day that the Barunga Agreement was struck, a newly elected South Australian government formally stepped away from its predecessor's commitment to treaty-making, declaring them 'expensive gestures'. ${ }^{32}$

The South Australian decision is a step backwards, but political leaders in several other states have indicated that they support treaty. The New South Wales Labor opposition had promised to hold treaty talks with Aboriginal nations within the state if it had won the 2019 state election. The Tasmanian Labor opposition made a similar promise, though it failed to secure election in 2018. The South Australian opposition has also recently reaffirmed its support for treaty negotiations, while at the national level, the Labor opposition remains committed to treaty, as part of its support for the Uluru Statement from the Heart.

\section{Potential challenges}

The Queensland government's decision is momentous but the treaty process itself is only in its preliminary stages. As the abandoned negotiations in South Australia demonstrate, there is no guarantee that the process will lead to any agreement. Although many challenges will arise during the negotiation phase, several immediately present themselves.

First, Queensland has only recently formally adopted a treaty process, but the same question that has followed announcements in Victoria, the Northern Territory, and South Australia, have already arisen: Is it legitimate or appropriate for states and territories to enter negotiations with Aboriginal and Torres Strait Islander peoples? In a recent paper, George Williams and I argue that the States and Territories have the legal authority to enter into treaties with First Nations. However, as we note, many Aboriginal and Torres Strait Islander peoples may remain concerned that negotiating with subnational governments may detract from or challenge their sovereign status. ${ }^{33}$ Gumatj leader Galarrwuy Yunupingu gave voice to this view at the Barunga Festival in June 2018:

None of the land councils can tell me anything about treaty. What does the word treaty mean? Nothing. It means nothing to Yolngu people. The men offering us the word treaty, will it be nice or will it be no good? It has to be the federal government and not the Northern Territory government. ${ }^{34}$

\footnotetext{
${ }^{30}$ Advancing the Treaty Process with Aboriginal Victorians Act 2018 (Vic) preamble.

${ }^{31}$ Barunga Agreement, The Aboriginal Land Councils-Northern Territory, signed 8 June 2018 (Memorandum of Understanding) 6.

${ }^{32}$ Michael Owen, 'Aboriginal People Failed by “Expensive Gesture” Treaties', The Australian, 11 June 2018.

${ }^{33}$ See generally Hobbs and Williams (n 2) 217-227.

${ }^{34}$ Galarrwuy Yunupingu (Speech, Barunga Agreement Signing, 8 June 2018), cited in Chelsea Heaney, 'NT Signs Historic Barunga Agreement to Begin Indigenous Treaty Talks', NT News, 8 June 2018.
} 
Second, although Aboriginal and Torres Strait Islander peoples have called for treaties for generations, Indigenous peoples' support for these processes is not assured. Increasingly, First Nations are resisting agreement making with governments that act inconsistently with their values and aspirations. ${ }^{35}$ For instance, in Victoria, the Djab Wurrung Embassy, a group of traditional owners protesting VicRoads' plan to cut down sacred trees, has launched a 'No Trees, No Treaty' campaign to highlight the state government's refusal to listen to their views. ${ }^{36}$ Similarly, the Yorta Yorta Elders Council has also rejected a potential Victorian treaty as 'a pathway to assimilation' ${ }^{37}$ It would not be surprising if, for example, the Queensland government's support for the Adani coalmine leads First Nations to conclude that their negotiating partner may not be acting in good faith.

Third, it will be interesting to see whether and how the treaty process interacts with Queensland's recently enacted Human Rights Act 2019 (Q1d). In the preamble to the Act, the right to selfdetermination is recognised as being 'of particular significance' to Aboriginal and Torres Strait Islander peoples, but any operative rights are limited to cultural matters. While a treaty should empower First Nations with the authority to 'enjoy, maintain, control, protect and develop' their identity and cultural heritage, it must also recognise or establish mechanisms of self-governance. The Human Rights Act is positive, but a treaty must go further. ${ }^{38}$

Finally, the push towards treaty at the State and Territory level has exposed a fault line in the debate on constitutional recognition. In the Uluru Statement from the Heart, Aboriginal and Torres Strait Islander peoples called for the establishment of a constitutionally entrenched First Nations Voice to advise the federal Parliament on issues affecting Indigenous Australians. This is a worthwhile and modest proposal, which has secured considerable support throughout the Australian community. ${ }^{39}$ However, the Coalition government has ruled out a referendum on this question. ${ }^{40}$ The government's position places those who support the Uluru Statement in a difficult position.

Of course, the Uluru Statement also called for the establishment of a Makarrata Commission to supervise a process of agreement making (and truth telling) across the country, but the Voice has been prioritised. ${ }^{41}$ This strategy reflects a number of political and legal considerations. Among others, these include the fact that State and Territory treaties are vulnerable to Commonwealth legislative interference, and that without an effective Indigenous voice in Canberra or relevant capital city, State and Territory treaty processes may not last a change of government. Concerns also exist that meaningful settlements will take many years to negotiate within which time a representative body could effectively advocate for a wide range of Indigenous interests, as well as general cynicism that the State and Territory processes will not ultimately result in anything worthwhile. These are all legitimate concerns. The history of British and Australian governance on this continent strongly suggests that governments must meet a high burden of proof in convincing Aboriginal and Torres Strait Islander peoples that their newfound interest in treaty is not disingenuous.

However, as long as the federal government refuses to engage, the central question remains: What should Indigenous Australians and those who support a fairer distribution of political power do? While we can (and should) advocate for a First Nations Voice, should we ignore the State and Territory treaty processes? I do not think so. These processes have their challenges and they may not be perfect but they

\footnotetext{
${ }^{35}$ Hobbs, Whittaker and Coombes (n 19).

${ }^{36}$ Madeline Haymen-Reber, 'No trees, no treaty: protestors continue to amass at Djab Wurrung site', NITV, 26 August 2019.

${ }^{37}$ Brooke Fryer, "Farcical": Yorta Yorta Elders Council rejects treaty with Victoria', NITV, 26 June 2019.

${ }^{38}$ See Harry Hobbs, 'Treaty making and the UN Declaration on the Rights of Indigenous Peoples: lessons from emerging negotiations in Australia' (2019) 23(1-2) International Journal of Human Rights 174, 184.

39 Calla Wahlquist, 'Most Australians support Indigenous voice to parliament plan that Turnbull rejected', Guardian Australia, 30 October 2017.

${ }^{40}$ Ken Wyatt, '19th Annual Vincent Lingiari Memorial Lecture' (Charles Darwin University, 15 August 2019).

${ }^{41}$ Megan Davis, 'The Long Road to Uluru: Walking Together' (2018) 60 Griffith Review 13, 30.
} 
are valuable. The Queensland treaty process, like its counterparts in Victoria and the Northern Territory, may lead to meaningful settlements that secure important outcomes for the Aboriginal and Torres Strait Islander communities that sign them. Additionally, in propelling the debate forward, these processes are building political and moral pressure on other governments within Australia-including the Commonwealth. In other words, State and Territory treaty processes could help force the federal government to change its position.

\section{Concluding thoughts}

It is too early to tell whether the Queensland process will be successful, but we do know that treaties will not resolve all of the challenges that Indigenous Australians face. Nonetheless, announcing a process of treaty making signals a commitment by government to listen to Aboriginal and Torres Strait Islander peoples and meaningfully address their aspirations. If the Queensland government is sincere, the treaty process offers the potential to rebuild Aboriginal and Torres Strait Islander nations and reempower Aboriginal and Torres Strait Islander peoples, enabling them to play a meaningful role in the development and implementation of solutions to problems faced by their communities. It also offers the potential for Australian governments to legitimate their existence. 